\title{
Vazba a možnosti elektronické kontroly obviněného
}

\section{Arrest and Possibilities of Electronic Control of the Accused}

\author{
Roman Vicherek $^{*}$
}

\begin{abstract}
Abstrakt
$V$ zárú 2018 byla koněně fakticky spuštèna elektronická kontrola prostřednictvím elektronického monitorovacího systému. Kromě kontroly trestu domácího vězení, ke kterému je elektronická kontrola primárnè uř̌ená, je možné tuto kontrolu využit i jako omezeni, které zpř̌sni opatrením nabrazujici vaz̧bu podle $\int 73$ odst. 4 TrŘ. Právě možnost, nebo spiše nemožnost vyư̌ití elektronické kontroly k nabraženi vazby $v$ pröpravném řzeni se ukáazala jako problematická. Na tuto situaci a pruni postreby, které vyplynuly pri konzultacích mezi soudci, státnimi zástupci a PMS, poukazuje tento článek.
\end{abstract}

\section{Klíčová slova}

Dîvody vazby; elektronický monitoring; elektronická kontrola.

\begin{abstract}
In September 2018, electronic control was finally launched via electronic monitoring system. In addition to controlling the house arrest, to which electronic control is primarily it is possible to use this control as a restriction that will tighten the binding substitution measure by $\int 73 / 4$. It is the possibility or rather the impossibility of using electronic control to replace binding in pre-trial proceedings proved problematic. On this situation and the first observations that came about consultations between judges, prosecutors and PMS points out this article.
\end{abstract}

\section{Keywords}

Reasons for Arrest; Electronic Monitoring; Electronic Control.

\section{Úvod}

Počet osob, které jsou v České republice vazebně stíhány, je stabilně poměrně vysoký, stejně jako počet osob ve výkonu trestu odnětí svobody. Výsledkem jsou přeplněné věznice. Jedna z moderních možností, jak snížit tento počet a přitom dosáhnout účelu vazby, je využít možnosti elektronického monitorování obviněného. Obviněný, který bude vědět, že je nonstop sledován a jeho pohyb zaznamenáván, nebude mít sklony k páchání další trestné činnosti, právě naopak.

\footnotetext{
* JUDr. Roman Vicherek, Ph.D., Krajský soud v Ostravě; Katedra trestního práva, Právnická fakulta, Univerzita Palackého, Olomouc / Regional Court in Ostrava; Department of Criminal Law, Faculty of Law, Palacký University, Olomouc, Czech Republic / E-mail: roman.vicherek@upol.cz
} 


\section{Obecné vymezení institutu vazby}

Obecně je možné vazbu definovat jako institut trestního řízení, s jehož použitím je obviněný na základě rozhodnutí oprávněného orgánu dočasně zbaven osobní svobody, aby mu bylo zabráněno vyhýbat se trestnímu stíhání nebo trestu tím, že by uprchl nebo se skrýval, mařit nebo ztěžovat objasnění věci nepřípustným působením na prameny důkazů nebo pokračovat v trestné činnosti. ${ }^{1}$ Obsahem vazby, jak vyplývá z rozhodování Ústavního soudu, ${ }^{2}$ je vymezení ústavně akceptovatelných důvodů omezení osobní svobody obviněného, resp. obžalovaného, s cílem znemožnit zmaření nebo ztížení dosažení účelu trestního řízení.

Institut vazby je nejvýznamnějším opatřením k zajištění osob pro účely trestního řízení. Jedná se o opatření, které má být užíváno fakultativně a subsidiárně, a to tehdy, nelze-li osobu zajistit jiným, méně omezujícím způsobem, který by mohl vazbu nahradit. Je nutné dospět $\mathrm{k}$ závěru, že vazba není na místě, jestliže by byla př́íným procesním zajišstovacím opatřením. ${ }^{3} \mathrm{~V}$ tomto směru trestní řád disponuje několika opatřeními nahrazujícími vazbu, které jsou upraveny v \ 73 odst. 1 z. č. 141/1961 Sb. trestního řádu (dále jen TrŘ), \ 73a TrŘ a \ 49 z. ̌́. 218/2003 Sb. o soudnictví ve věcech mládeže (dále jen ZSVM). Jednotlivá opatření jsou vždy spojena se zásahem do osobní svobody obviněného a mají za úkol především zajistit př́itomnost obviněného při úkonech trestního řízení, zabránit mu v jednání, jež by mohlo ohrozit či zmařit účel trestního řízení a zabránit obviněnému v pokračování v trestné činnosti.

Soud tedy může rozhodnout o vzetí do vazby pouze tehdy, nelze-li v době rozhodování účelu vazby dosáhnout jiným opatřením, $\mathrm{k}$ těmto opatřením nahrazujícím účel vazby patři:

a) Záruka zájmového sdružení občanů nebo důvěryhodné osoby schopná příznivě ovlivňovat chování obviněného, jestliže nabídnou převzetí záruky za další chování obviněného a za to, že se obviněný na vyzvání dostaví k soudu, státnímu zástupci nebo policejnímu orgánu a že vždy předem oznámí vzdálení se z místa pobytu, a orgán rozhodující o vazbě považuje záruku vzhledem k osobě obviněného a $\mathrm{k}$ povaze projednávaného př́padu za dostatečnou a přijme ji [ 73 odst. 1 písm. a) TrŘ].

b) Písemný slib obviněného [ $\int 73$ odst. 1 písm. b) TrŘ], ve kterém obviněný slíbí, že povede řádný život, zejména že se nedopustí trestné činnosti, na vyzvání se dostaví k soudu, státnímu zástupci nebo policejnímu orgánu, vždy předem oznámí vzdálení se z místa pobytu a že splní povinnosti a dodrží omezení, která se mu uloží, a orgán rozhodující o vazbě považuje slib vzhledem k osobě obviněného a k povaze projednávaného prŕpadu za dostatečný a přijme jej.

1 RƯŽIČKA, Miroslav a Jana ZEZULOVÁ. Zadř̌eni a važba v českém trestním procesu. 1. vyd. Praha: C. H. Beck, 2004, s. 369.

2 Nález ÚS 46/1993-94-n, ÚS 24/1997-n, ÚS 156/1999-n., ÚS 12/2002-u.

3 ŠÁMAL, Pavel a kol. Trestní rád. Komentár. 7. vyd. Praha: C. H. Beck, 2013, s. 733. 
c) Dohled probačního úředníka [ 73 odst. 1 písm. c) TrŘ], pokud s ohledem na osobu obviněného a povahu projednávaného případu lze účelu vazby dosáhnout tímto dohledem nad osobou obviněného.

d) Uložení předběžného opatření podle $\int 88 \mathrm{~b}$ a násl. TrŘ.

e) Peněžitá záruka [ $\left.\int 73 \mathrm{a} \operatorname{TrŘ}\right]$, pokud soud přijme složenou peněžitou záruku, jejíž výši určil.

f) U mladistvého navíc přichází v úvahu náhrada vazby jeho umístěním v péči důvěryhodné osoby, a to za předpokladu, že taková osoba je ochotná a schopná se ujmout péče o mladistvého a dohledu nad ním, písemně se zaváže, že bude o mladistvého pečovat a převezme odpovědnost za to, že se mladistvý na předvolání dostaví k př́islušnému orgánu, popř̀. splní i další podmínky, které určí soud.

Jednotlivá opatření nahrazující vazbu lze uložit samostatně nebo i vedle sebe, a to popríípadě i za současného uložení omezení spočívajícího v zákazu vycestování do zahraničí [S 73 odst. 5 TrŘ]. S účinností od 1. 7. 2016 zákonem č. 150/2016 Sb. přibylo do trestního řádu další omezení, které je možné uložit v souvislosti nahrazením vazby některým z výše uvedeným opatřením, a to výkonem elektronické kontroly podle $₫ 73$ odst. 4 TrŘr. Tomuto omezení je poté věnována i další část tohoto př́spěvku.

\section{Aktuální trendy v oblasti vazby}

\subsection{Vazba v př́ípravném řízení ${ }^{4}$}

\begin{tabular}{|c|c|c|c|c|c|}
\hline \multirow{2}{*}{$\begin{array}{l}\text { Rok } \\
2008\end{array}$} & \multirow{2}{*}{$\begin{array}{c}\text { Zahájená trestní } \\
\text { stíhání } \\
62.664\end{array}$} & \multicolumn{2}{|c|}{$\begin{array}{c}\text { Podané návrhy na vzetí } \\
\text { do vazby SZ }\end{array}$} & \multicolumn{2}{|c|}{ Vzetí do vazby soudem } \\
\hline & & 4488 & $7,2 \%$ & 3951 & $88,0 \%$ \\
\hline 2009 & 45.807 & 4317 & $9,4 \%$ & 3838 & $88,9 \%$ \\
\hline 2010 & 40.506 & 4670 & $11,5 \%$ & 4027 & $86,2 \%$ \\
\hline 2011 & 40.342 & 4623 & $11,5 \%$ & 4065 & $87,9 \%$ \\
\hline 2012 & 32.977 & 4295 & $13,0 \%$ & 3673 & $85,5 \%$ \\
\hline 2013 & 30.790 & 4437 & $14,4 \%$ & 3803 & $85,7 \%$ \\
\hline 2014 & 29.701 & 4195 & $14,1 \%$ & 3600 & $85,8 \%$ \\
\hline 2015 & 36.575 & 3748 & $10,2 \%$ & 3250 & $86,7 \%$ \\
\hline 2016 & 35.322 & 3636 & $10,3 \%$ & 3138 & $86,3 \%$ \\
\hline 2017 & 33.031 & 3368 & $10,2 \%$ & 2961 & $87,9 \%$ \\
\hline $2018 *$ & 16.154 & 1546 & $9,6 \%$ & 1352 & $87,4 \%$ \\
\hline
\end{tabular}

* Za období od 1. 1. do 30. 6. 2018.

4 MINISTERSTVO SPRAVEDLNOSTI. Výkaz o vaz̧ách V(MS)-007 [online]. [cit. 10. 11. 2018]. Dostupné z: http://cslav.justice.cz/InfoData/vykazy-soudu-a-statnich-zastupitelstvi.html 


\begin{tabular}{|c|c|c|c|c|c|c|c|}
\hline Rok & $\begin{array}{c}\text { Vazby } \\
\text { skončeno }\end{array}$ & Obžalobou & $\%$ & $\begin{array}{c}\text { Dohodou } \\
\text { o vině a trestu }\end{array}$ & $\begin{array}{c}\text { Propuštění } \\
\text { SZ }\end{array}$ & $\begin{array}{c}\text { Propuštění } \\
\text { soudem }\end{array}$ & $\%$ \\
\hline $\mathbf{2 0 0 8}$ & 4110 & 3131 & $\mathbf{7 6 , 1}$ & - & 521 & 205 & $\mathbf{1 7 , 7}$ \\
\hline $\mathbf{2 0 0 9}$ & 4055 & 3166 & $\mathbf{7 8 , 1}$ & - & 465 & 206 & $\mathbf{1 6 , 5}$ \\
\hline $\mathbf{2 0 1 0}$ & 4117 & 3193 & $\mathbf{7 7 , 6}$ & - & 485 & 203 & $\mathbf{1 6 , 7}$ \\
\hline $\mathbf{2 0 1 1}$ & 4222 & 3265 & $\mathbf{7 7 , 3}$ & - & 519 & 176 & $\mathbf{1 6 , 5}$ \\
\hline $\mathbf{2 0 1 2}$ & 4029 & 2962 & $\mathbf{7 5 , 3}$ & 6 & 518 & 271 & $\mathbf{1 9 , 6}$ \\
\hline $\mathbf{2 0 1 3}$ & 3931 & 2982 & $\mathbf{7 5 , 9}$ & 11 & 450 & 304 & $\mathbf{1 9 , 2}$ \\
\hline $\mathbf{2 0 1 4}$ & 3820 & 2663 & $\mathbf{6 9 , 7}$ & 1 & 566 & 350 & $\mathbf{2 4 , 0}$ \\
\hline $\mathbf{2 0 1 5}$ & 3491 & 2544 & $\mathbf{7 2 , 9}$ & 8 & 483 & 284 & $\mathbf{2 2 , 0}$ \\
\hline $\mathbf{2 0 1 6}$ & 3290 & 2366 & $\mathbf{7 1 , 9}$ & 2 & 445 & 281 & $\mathbf{2 2 , 1}$ \\
\hline $\mathbf{2 0 1 7}$ & 3153 & 2313 & $\mathbf{7 3 , 4}$ & 3 & 415 & 244 & $\mathbf{2 0 , 9}$ \\
\hline $\mathbf{2 0 1 8}$ & 1453 & 1042 & $\mathbf{7 1 , 7}$ & 3 & 176 & 92 & $\mathbf{1 8 , 4}$ \\
\hline
\end{tabular}

* Za období od 1. 1. do 30. 6. 2018.

Ze statistik týkajících se vazebního řízení je možné vyčíst více méně setrvalý stav. Ačkoliv celkový počet podaných návrhů na vzetí do vazby soustavně klesá (od roku 2010 o 27 \%), pak je tento stav zaprŕíčiněn snižující se mírou trestné činnosti, resp. klesajícím počtem zahájených trestních stíhání. Proto pokud jde o poměr množství podaných návrhů na vzetí do vazby $\mathrm{k}$ počtu zahájených trestních stíhání, tak tento se nijak výrazně nemění. V ČR je přibližně v 10 \% případů vedeno trestní stíhání vazebně, kdy nepatrně větší počet vazebních řízení byl v roce 2012-2014 (cca 14 \%). Soudy vyhoví návrhu státního zástupce na vzetí do vazby přibližně v $87 \%$ případů, což je poměrně vysoké číslo. Nepatrně nižší poměr vyhovění žádostem o vzetí do vazby je pak zaznamenán v době, kdy státní zástupci podávali větší počet návrhu na vzetí do vazby, než je dlouhodobý průměr, tedy v letech 2012-2014, ale i zde se jednalo jen o nepatrný rozdíl (85,6 \% žádosti). Vazba $\mathrm{v}$ přípravném řízení většinou nekončí a pokračuje i v soudním stadiu trestního řízení, obžaloba je podána v prípadě vazebního řízení v $75 \%$. Pokud jde o osoby propuštěné z vazby $\mathrm{v}$ přípravném řízení, tak se jedná přibližně o $20 \%$, z nichž $2 / 3$ pustî státní zástupce a $1 / 3$ poté soud. 
2.2 Využití opatření nahrazující vazbu v přípravném řízení v roce $2018^{5}$

\begin{tabular}{|c|c|c|c|c|}
\hline & Skončeno vazeb & $\int 73$ a $73 a \operatorname{TrR}$ & $\%$ & $\int 73$ odst. 4 TrŘ \\
\hline $1 / 2018$ & 201 & 10 & & 0 \\
\hline $2 / 2018$ & 183 & 7 & & 0 \\
\hline $3 / 2018$ & 243 & 12 & & 0 \\
\hline $4 / 2018$ & 270 & 15 & & 0 \\
\hline $5 / 2018$ & 224 & 8 & & 0 \\
\hline $6 / 2018$ & 261 & 15 & & 0 \\
\hline $7 / 2018$ & 199 & 10 & & 0 \\
\hline $8 / 2018$ & 245 & 18 & & 1 (JČ OSZ) \\
\hline $9 / 2018$ & 201 & 21 & & 2 (JČ OSZ, Praha MSZ) \\
\hline $10 / 2018$ & 216 & 9 & & 0 \\
\hline Celkem & 2243 & 125 & $5,6 \%$ & 3 \\
\hline
\end{tabular}

Od roku 2018 je v rámci výkazu vazeb v přípravném řízení sledováno i nahrazení vazby některým z opatření uvedených v $\int 73$ a 73 a Trर̌R. Byt' se jedná prozatím o krátké období, po které jsou tato data sbírána (10 měsíců), můžeme říci, že propuštění z vazby za současného přijetí některého z opatření nahrazující vazbu je spíše mimořádné a v průměru takto končí jen 5,6 \% př́padů. Od 1. 1. 2018 je v přípravném řízení nově sledováno, v kolika prŕpadech došlo k nahrazení institutu vazby opatřením podle $\int 73$ a $73 \mathrm{a} \operatorname{Tr} \mathrm{R}$ ze současného uložení omezení podle $\int 73$ odst. 4 TrŘ, tedy za současného uložení elektronické kontroly. Doposud k tomuto došlo jen ve 3 př́padech (do 1. 11. 2018), a to 2x na OSZ v Jižních Čechách a 1x u MSZ v Praze.

\subsection{Vazba v ř́zení před soudem ${ }^{6}$}

\begin{tabular}{|c|c|c|c|}
\hline & Skončeno & S dohledem & Na kauci \\
\hline $\mathbf{2 0 0 8}$ & 5045 & 37 & 19 \\
\hline $\mathbf{2 0 0 9}$ & 5125 & 42 & 14 \\
\hline $\mathbf{2 0 1 0}$ & 5107 & 42 & 17 \\
\hline $\mathbf{2 0 1 1}$ & 5074 & 43 & 5 \\
\hline $\mathbf{2 0 1 2}$ & 4877 & 46 & 18 \\
\hline $\mathbf{2 0 1 3}$ & 4354 & 74 & 16 \\
\hline $\mathbf{2 0 1 4}$ & 4176 & 73 & 7 \\
\hline $\mathbf{2 0 1 5}$ & 3907 & 79 & 9 \\
\hline $\mathbf{2 0 1 6}$ & 3530 & 58 & 3 \\
\hline $\mathbf{2 0 1 7}$ & 3402 & 39 & 2 \\
\hline $\mathbf{2 0 1 8}$ & 1660 & 25 & 8 \\
\hline
\end{tabular}

* Za období od 1. 1. do 30. 6. 2018.

5 MINISTERSTVO SPRAVEDLNOSTI. Výkaz o vaz̧bách V(MS)-O07 [online]. [cit. 10. 11. 2018]. Dostupné z: http://cslav.justice.cz/InfoData/vykazy-soudu-a-statnich-zastupitelstvi.html

6 MINISTERSTVO SPRAVEDLNOSTI. Výkaz o vazáách V(MS)-111 [online]. [cit. 10. 11. 2018]. Dostupné z: http://cslav.justice.cz/InfoData/vykazy-soudu-a-statnich-zastupitelstvi.html 
V soudním stadiu trestního řízení je ve vztahu k opatřením nahrazující vazbu sledován počet propuštění z vazby za současného stanovení dohledu [S 73 odst. 1 písm. c) TrŘ] a propuštění z vazby na základě přijetí peněžité záruky ( $\left.\int 73 \mathrm{a} \operatorname{TrR}\right)$. V obou př́ipadech můžeme shledat poměrně nízké využití. $V$ prípadě dohledu dochází k propuštění z vazby $\mathrm{v}$ desítkách př́ipadu ročně (37-79 propuštění za rok), v př́ípadě peněžitých záruk se jedná spíše o jednotky (3-19 propuštění za rok). Důvodem je, že jsou-li u obviněného dány důvody vazby a je třeba přistoupit $\mathrm{k}$ některému zajišt'ujícímu opatření, rizika spojená s ponecháním obviněného na svobodě jsou zpravidla tak vysoká, že soudy k rozhodnutím odlišným od vzetí do vazby přistupují jen velmi zdrženlivě.

Častější využívání alternativních opatření za vazbu by mohlo rovněž do určité míry přispět $\mathrm{k}$ řešení neprřiznivé situace $\mathrm{v}$ českém vězeňství, kdy počty obviněných ve vazbě, jakož i jejich podíl na celkové vězeňské populaci, představují dlouhodobě z pohledu vězeňských kapacit a z pohledu financování této oblasti problém.

\section{4 Členění obviněných dle délky vykonávané vazby $\mathrm{k} 31.12 .2017^{7}$}

\begin{tabular}{|l|c|c|}
\hline Délka vazby & Osob & $\%$ \\
\hline Do 2 měsíců & 577 & 31,9 \\
\hline 2 až 4 měsíce & 408 & 22,6 \\
\hline 4 až 6 měsíců & 257 & 14,2 \\
\hline 6 až 9 měsíců & 254 & 14,0 \\
\hline 9 měsíců až 1 rok & 137 & 7,6 \\
\hline 1 rok až 2 roky & 162 & 9,0 \\
\hline Nad 2 roky & 14 & 0,7 \\
\hline Celkem & 1809 & 100 \\
\hline
\end{tabular}

V roce 2017 bylo ve vazbě v průměru 1860 osob, což činní asi 8,5 \% ze všech osob ve věznicích. Většinu vazeb se daří vyřešit rychle, do 6 měsíců je to $69 \%$. Jednou z možností, jak snížit počet osob ve vazbě a zvýšit využití opatření nahrazující institut vazby, je využití elektronické kontroly podle $\int 73$ odst. 4 TrŘ́, kterou zákonodárce sice včlenil do trestního řádu již s účinností od 1. 7. 2016, z.č. 150/2016 Sb., nicméně doposud nebyla vůbec využívána s ohledem na skutečnost, že nebylo k dispozici technické rešení pro elektronickou kontrolu.

\section{Dlouhá cesta $\mathrm{k}$ elektronickému monitoringu v ČR}

Otázka elektronického monitoringu se neobjevila až v roce 2016, Ministerstvo spravedlnosti tento problém řeši již někdy od roku 2010 v souvislosti s realizací trestu domácího

7 VĚZEŇSKÁ SLUŽBA ČR. Statistická rǒ̌enka Vězeňské služby za rok 2017 [online]. [cit. 10. 11. 2018]. Dostupné Z: https://www.vscr.cz/wp-content/uploads/2018/10/Statistick\%C3\%A1-ro\%C4 \%8Denka-2017.pdf 
vězení. Dne 1. 7. 2012 byl zahájen pilotní projekt „Elektronický monitoring odsouzených", jehož cílem bylo experimentálně ověřit provoz elektronického monitoringu a využít získané zkušenosti pro přípravu zavedení této metody kontroly odsouzených ke standardnímu využívání. $\mathrm{V}$ té době se ještě neuvažovalo o možnosti využít elektronický monitoring i u obviněných $\mathrm{v}$ rámci rozhodování o vazbě, ale toliko u trestu domácího vězení. Ve výběrovém řízení bylo vybráno elektronické monitorovací zařízení, které bylo následně experimentálně vyzkoušeno na 43 dobrovolnících z řad odsouzených a na 4 probačních úřednících (rovněž dobrovolnících). Výsledné zkušenosti vedly $\mathrm{k}$ závěru, že provozovatelem elektronického monitoringu by měla být Probační a mediační služba ČR (dále jen PMS), jelikož by takové řešení bylo levnější, než pokud by byl provoz systému elektronického monitoringu zajišt'ován externím dodavatelem. V konečném důsledku bylo na základě úspěšné realizace experimentu doporučeno, aby byl systém elektronického monitoringu odsouzených zaveden pro širší využití v rámci výkonu trestní spravedlnosti, konkrétně bylo doporučeno zakoupit 500 až 2000 zařízení pro elektronické monitorování. ${ }^{8}$

Následně dne 15. 2. 2013 byla zveřejněna zakázka na dodávku a zajištění provozu zařízení sloužícího $\mathbf{k}$ elektronickému monitorování odsouzených k trestu domácího vězení, jejúž odhadovaná hodnota činila 229500000 Kč. Nicméně amnestií prezidenta republiky z ledna 2013 došlo k prominutí mj. i uložených trestů domácího vězení (srov. čl. IV odst. 2 rozhodnutí prezidenta republiky publikovaného pod č. 1/2013 Sb.), takže se počet odsouzených k tomuto trestu „vynuloval“ a vypsaná veřejná zakázka se stala nerentabilní. Veřejná zakázka byla proto ukončena před její realizací.

Kopětovnému odstartování projektu elektronického monitoringu došlo v říjnu 2014, kdy byla vytvořena pracovní skupina EMSON (Elektronický monitorovací systém „ON“), jejímž primárním cílem byla př́prava podkladů $\mathrm{k}$ realizaci veřejné zakázky na zavedení elektronického monitorovacího systému pro trestní justici. ${ }^{9} \mathrm{~V}$ lednu 2015 byla PMS pověřena realizací nadlimitní veřejné zakázky $\mathrm{k}$ projektu elektronického monitorovacího systému pro trestní justici, předběžné oznámení bylo zveřejněné 2. 1. 2015. ${ }^{10}$ Spol. KPMG vypracovala studii proveditelnosti zavedení elektronického monitorovacího systému pro trestní justici, tato studie byla publikována v červenci 2015. V prosinci 2015 došlo ke zrušení zakázky na elektronický monitorovací systém pro malý zájem účastníků.

8 PROBAČNÍ A MEDIAČNÍ SLUŽBA ČESKÉ REPUBLIKY. Závěrečná zpráva a ekonomické z̧hodnocení pilotního projek.tu: „Elektronický monitoring odsouzených“ “[online] [cit. 10. 11. 2018]. Dostupné z: https://www. pmscr.cz/download/zaverecna_zprava_o_experimentu_Elektronicky_monitoring_odsouzenych.pdf

9 MINISTERSTVO SPRAVEDLNOSTI. Ministerstvo spravedlnosti znovu odstartovalo projekt eleketronickébo monitorovacího systému [online]. Publikováno 31. 10. 2014 [cit. 10. 11. 2018]. Dostupné z: http://portal. justice.cz $/$ Justice2/MS $/ \mathrm{ms}$. aspx?o $=23 \& j=33 \& \mathrm{k}=6365 \& \mathrm{~d}=339047$

10 MINISTERSTVO SPRAVEDLNOSTI. Př́prava projektu elektronického monitorovacího systému pro trestní justici vstoupila do dalši fáze. [online]. Publikováno 5. 1. 2015 [cit. 10. 11. 2018]. Dostupné z: http://portal. justice.cz/Justice2/MS/ms.aspx?o $=23 \& j=33 \& \mathrm{k}=6365 \& \mathrm{~d}=340131$ 
Naposledy byla zakázka vypsána 29. 2. 2016. Byla zvolena forma tzv. soutěžního dialogu. ${ }^{11}$ Vítězem soutěžního dialogu byla dne 21. 2. 2017 vyhlášená spol. SuperCom. Pořízení náramku a provoz monitorovacího centra na 6 let bude stát 93 mil. korun. ${ }^{12}$ PMS uzavřela se společností SuperCom smlouvu dne 26. 9. 2017. V první fázi projektu získalo ministerstvo od SuperComu 280 náramků, provoz monitorovacího centra a školení zaměstnanců. $\mathrm{V}$ dalších šesti letech bude moci využívat až 2000 zařízení podle aktuální potřeby. Náklady na jednoho odsouzeného a jeden den domácího vězení byly vyčísleny na 130 Kč. ${ }^{13}$ Náramky byly testovány na zaměstnancích PMS, kdy bylo nutné „vyladit“ systém. Ostrý start systému byl spuštěn v polovině září 2018. ${ }^{14}$

Původně tedy nebylo vůbec počítáno s možností, že by elektronický monitoring byl využit i v prrípadě vazby, jako omezení, které může zintenzivnit opatření nahrazující vazbu. Tato myšlenka se objevila postupně, a nakonec došlo k zapracování elektronického monitoringu (formou elektronické kontroly) do trestního řádu s účinností od 1. 7. 2016, z. č. 150/2016 Sb., a to do ustanovení $\int 73$ odst. 4 TrŘR, současně se zavedením kontroly výkonu trestu domácího vězení \ 334 b TrŘ a \360a TrŘ výkon elektronické kontroly plnění povinností uložených v souvislosti s některým opatřením nahrazujícím vazbu.

Cílem této novely bylo zefektivnit kontrolu plnění podmínek a omezení uložených obviněnému v rámci některého opatření nahrazujícího vazbu, a to za pomoci využití elektronické kontroly. Tímto způsobem měla být zajištěna vyšší účinnost a častější ukládání opatření nahrazujících vazbu v prrípadech, kdy není nezbytná nepřetržitá fyzická kontrola obviněného. Častější ukládání směřuje především na obviněné, u kterých vzhledem k jejich osobním poměrům a okolnostem př́padu není možné za současného stavu účelu vazby dosáhnout alternativním opatřením. Druhotným aspektem častějšího stíháním obviněných na svobodě má být i snížení stavu vězeňské populace a zachování sociálních vazeb (především zachování rodinných vazeb, zaměstnání a možnosti volnočasových aktivit) obviněných.

Z důvodové zprávy k z. č. 150/2016 Sb. vyplývá, že z poznatků získaných z dotazníkového šetření, Institut pro kriminologickou prevenci (dále jen IKSP) tento odhadl, že př́padný pozitivní dopad zavedení elektronického sledování jako alternativy za vazbu na vězeňskou populaci by mohl představovat (byt’ v závislosti na konkrétní podobě prrijatého

11 MINISTERSTVO SPRAVEDLNOSTI. Ministerstvo spravedlnosti a Probačni a mediačni služba vypisuji novou zakázku na tzv. „elektronické náramky" [online]. Publikováno 5. 4. 2016 [cit. 10. 11. 2018]. Dostupné z: http:/ / portal.justice.cz/Justice2/MS/ms.aspx?o=23\&j=33\&k=6365\&d=347925

12 ČTK. Náramky pro vězně dodá firma SuperCom za 93 milionů korun. Céská justice.cz. [online]. Publikováno 22. 2. 2017 [cit. 10. 11. 2018]. Dostupné z: http://www.ceska-justice.cz/2017/02/ naramky-pro-vezne-doda-firma-supercom-za-93 milionu-korun/

13 ČTK. Probační služba uzavřela smlouvu na náramky pro vězně, řízení u ÚOHS stále trvá. Ceská justice.cそ. [online]. Publikováno 26. 9.2017 [cit. 10. 11. 2018]. Dostupné z: http://www.ceska-justice.cz/2017/09/ probacni-sluzba-uzavrela-smlouvu-na-naramky-pro-vezne-rizeni-u-uohs-stale-trva/

14 ČTK. Ministerstvo v tichosti spustilo náramky pro vězně, zatím kontrolují 30 odsouzených. Ceskájustice.cz [online]. Publikováno 21. 9. 2018 [cit. 10. 11. 2018]. Dostupné z: http://www.ceska-justice.cz/2018/09/ ministerstvo-tichosti-spustilo-naramky-vezne-zatim-kontroluji-30-odsouzenych/ 
řešenî) snížení průměrného stavu osob vězněných ve vazební věznici $\mathrm{k}$ určitému dni o řádově desítky či několik málo stovek obviněných. Celkový počet obviněných, u kterých by bylo možno nahradit vazbu za použití elektronické kontroly, nicméně Vězeňská služba kvalifikovaně odhadla na cca $10 \%$ vazebně stíhaných osob, tedy cca 200 osob. ${ }^{15}$

\section{Elektronický monitoring jako institut nahrazující vazbu v zahraničí}

Ke sjednocení praxe v jednotlivých evropských zemích při aplikaci elektronických monitorovacích systémů by mělo přispět i poslední doporučení Rady Evropy z 19. 2. 2014 CM/Rec (2014)4E, ${ }^{16}$ kde je výslovně zdůrazněno, že uplatňování těchto nových technologií v oblasti trestní politiky musí být přměřené a dobře legislativně upravené, aby byly minimalizovány případné negativní vedlejší dopady na privátní sféru odsouzeného, resp. kontrolovaného. ${ }^{17}$ Systém elektronického monitoringu má v jednotlivých zemích široké využití, využívá se jako náhrada vazby, v případě výkonu trestu (např. domácího vězenî), a také v prípadech podmíněného propuštění, a to jako tzv. front-door („,vstupní‘) nebo back-door (,,výstupní“) alternativa.

V některých evropských zemích (např. Anglie, Wales, Švýcarsko, Portugalsko, některé země Spolkové republiky Německo) je při nahrazování vazby v trestním řízení alternativními opatřeními využíván systém elektronického sledování, a to bud' jako samostatné opatření nahrazující vazbu, nebo jako kontrolní prvek v př́padě nahrazení vazby některým jiným opatřením, které daný právní rád jako alternativu $\mathrm{k}$ vazbě připouští. Vždy se však jedná o opatření, jehož podstatou nebo součástí je povinnost obviněného zdržovat se v určenou dobu na stanoveném místě, přičemž elektronické sledování zajišt'uje kontrolu plnění této povinnosti.

V Anglii a Walesu využívají možnost elektronického monitoringu vazebně stíhaných od roku 1995. Pokud jde o počty monitorovaných osob (údaje jsou k 31. 10. 2011), v př́ipadě vazby bylo sledováno 9419 osob, jako samostatné trestní sankci nahrazující trest odnětí svobody se podrobilo 6618 odsouzených. Elektronický dohled jako součást jiné trestní sankce mělo uloženo soudem 5755 pachatelů. Při podmíněném propuštění bylo monitorováno 3326 osob. $^{18}$

15 Důvodová zpráva k zákonu č. 150/2016 ze dne 25. 5. 2015. beck-online [online]. [cit. 10. 11. 2018]. Dostupné $\quad z: \quad$ https://www.beck-online.cz/bo/chapterview-document.seam?documentId= oz5f6mrqge3f6mjvgbpwi6romnqtc\&groupIndex $=0 \&$ rowIndex $=0$

16 Doporučení $C M / \operatorname{Rec}$ (2014) 4, Výboru ministru členských státio o elektronickém monitoringu [online] [cit. 10. 11. 2018]. Dostupné z https://www.pmscr.cz/download/Mezinarodni_spoluprace_DOPORUCENI_RADY_EVROPY_K_EL_MONITORINGU.pdf

17 SCHEINOST, Miroslav, Helena VÁLKOVÁ a kol. Sankéni politika a jeji uplatňování. Praha: IKSP, 2015, s. $72-73$.

18 MINISTERSTVO SPRAVEDLNOSTI ČR. Zahranični żkušenosti s elektronickým monitoringem. Medailónky jednotlivých zemi - Anglie a Wales [online] [cit. 1. 11. 2018]. Dostupné z: http://portal.justice.cz/Justice2/ $\mathrm{MS} / \mathrm{ms} \cdot \mathrm{aspx} ? \mathrm{j}=33 \& \mathrm{o}=23 \& \mathrm{k}=6368 \& \mathrm{~d}=338780$ 
K širšímu rozpětí využití elektronického monitoringu na regionální úrovni se hlásí Hessensko. Variantami pro užití „,náramků“ zde může být náhrada vazby, aplikace elektronického sledování jako součásti jiné trestní sankce, forma výkonu trestu odnětí svobody, sledování u podmíněného propuštění z výkonu trestu odnětí svobody a monitoring po propuštění z vězení. Ke konci roku 2012 bylo v rámci náhrady vazby sledováno 50 osob, jedna osoba po propuštění z výkonu trestu a u zbylých možností bylo souhrnně deklarováno využití elektronického monitoringu u 40 případů. Provozovateli jsou Probační služba a soukromá společnost, užívána je radiofrekvenční technologie sledování. Průměrná délka období, po které je potrestaná osoba sledována, činí 42 dní. ${ }^{19}$

Podle údajů k 31. 12. 2012 bylo v Portugalsku monitorováno 495 osob, kterým elektronický monitoring nahrazoval vazbu, 100 odsouzených bylo sledováno pomocí elektronického monitoringu $\mathrm{v}$ rámci alternativy k trestu odnětí svobody a 15 jedinců bylo kontrolováno při podmíněném propuštění z výkonu trestu odnětí svobody. Monitoringu v prrípadech domácího násilí podléhalo 105 osob. O konci elektronického monitoringu $\mathrm{v}$ důsledku porušení podmínek rozhoduje soud, počet předčasných ukončení se pohybuje od cca $1 \%$ u náhrady výkonu trestu odnětí svobody přes $3 \%$ u náhrady vazby až po $4 \%$ u pachatelů domácího násilí. U kontroly podmíněného propuštění nedochází dle portugalských materiálů k žádným selháním. ${ }^{20}$

Ve Francii podle dostupných údajů k prosinci roku 2011 bylo v systému pomocí radiofrekvenční technologie monitorováno 190 osob, u kterých byla tímto opatřením nahrazena vazba, a téměř 8 tisíc osob, u nichž elektronický monitoring suploval trest odnětí svobody nebo byl prvkem kontroly při podmíněném propuštění z něj. Data o monitorování prostřednictvím systému GPS nebyla k dispozici. O ukončení elektronického sledování $\mathrm{v}$ důsledku porušení podmínek rozhoduje soudce, $\mathrm{v}$ př́padě podmíněného propuštění i státní zástupce. Míra předčasných ukončení činí dle francouzských pramenů necelých $7 \%$ u náhrady vazby, cca $5 \%$ u výkonu trestu odnětí svobody a prostého podmíněného propuštění z něj, u podmíněného propuštění s dohledem selhává však víc jak pětina $(21 \%)$ pachatelů. ${ }^{21}$

19 MINISTERSTVO SPRAVEDLNOSTI ČR. Zabraniční zkušnosti s elektronickým monitoringem. Medailónky jednotlivých zemí - Némecko. [online] [cit. 1. 11. 2018]. Dostupné z: http://portal.justice.cz/Justice2/MS/ ms.aspx?j $=33 \& o=23 \& \mathrm{k}=6368 \& \mathrm{~d}=338780$

20 MINISTERSTVO SPRAVEDLNOSTI ČR. Zabraniční ఇkušenosti s elektronickým monitoringem. Medailónky jednotlivých zemí - Portugalsko. [online] [cit. 1.11.2018]. Dostupné z: http://portal.justice.cz/Justice2/ $\mathrm{MS} / \mathrm{ms} \cdot \mathrm{aspx} ? \mathrm{j}=33 \& \mathrm{o}=23 \& \mathrm{k}=6368 \& \mathrm{~d}=338780$

21 MINISTERSTVO SPRAVEDLNOSTI ČR. Zabranični qkušenosti s elektronickeým monitoringem. Medailónky jednotlivých zemí - Francie. [online] [cit. 1. 11. 2018]. Dostupné z: http://portal.justice.cz/Justice2/ $\mathrm{MS} / \mathrm{ms} . \mathrm{aspx} ? \mathrm{j}=33 \& \mathrm{o}=23 \& \mathrm{k}=6368 \& \mathrm{~d}=338780$ 


\section{Jak elektronický monitorovací systém funguje v ČR}

Na organizaci činností spojených s elektronickou kontrolou prostřednictvím elektronického monitorovacího systému (dále jen EMS) se podílí místně př́slušné středisko PMS, krajské oddělení EMS a operační středisko Ministerstva spravedlnosti.

Pro orgány činné v trestním řízení zůstává partnerem pro komunikaci při projednávání případu obviněného či odsouzeného vedoucí př́padu - probační pracovník místně př́slušného střediska PMS, který odpovídá za celkové vedení prrípadu, zpracovává stanovisko ke vhodnosti využití EMS, informuje soudce o průběhu výkonu trestu (omezení nahrazení vazby). Specialista EMS je probační úředník, který provádí v rámci působnosti oddělení EMS výlučně technické a provozní činnosti spojené se zajištěním EMS $\mathrm{v}$ terénu, zajišt'uje instalaci koncových zařízení, řeší provozní incidenty, po technické stránce se podílí na posouzení podmínek pro výkon elektronické kontroly. Veškeré své poznatky předává vedoucímu případu, není tedy v přímém kontaktu s orgány činnými $\mathrm{v}$ trestním řízení. Operační stř̌edisko MSp provádí kontrolu monitorovaných osob $\mathrm{v}$ nepřetržitém provozu, při vzniku bezpečnostního či provozního incidentu bezodkladně kontaktuje monitorovanou osobu a řeší s ní aktuální situaci, informuje vedoucího př́padu o porušení podmínek elektronické kontroly monitorovanou osobou, neprodleně kontaktuje Policii ČR v případě bezpečnostního incidentu, tj. zásadního porušení podmínek monitorovanou osobou, u které bylo rozhodnuto o nahrazení vazby.

EMS je dostupný jako webová aplikace, která obsahuje všechny informace o monitorovaných a chráněných osobách, které jsou nezbytné pro výkon elektronické kontroly. K tomu využívá technická koncová zařízení. Základnová stanice je zařízení, které se umíst'uje v obydlí monitorované osoby. Zařízení vysílá rádiový signál, jehož intenzitu lze nastavit podle velikosti obydlí tak, aby signál pokrýval obydlí v celém rozsahu. Náramek je zařízení prúpevňované na dolní končetinu monitorované osoby v oblasti kotníku pomocí pevně připojeného popruhu. Přerušení popruhu je automaticky hlášeno zaměstnanci operačního střediska EMS. Pokud náramek není v dosahu základnové stanice, aktivuje se modul GPS pro lokalizaci místa, ve kterém se náramek nachází. Komunikátor, který je poskytnut monitorované osobě, je vlastně mobilní telefon s instalovanými aplikacemi a slouží ke komunikaci zaměstnanců PMS a operačního střediska s obviněnou nebo odsouzenou osobou. Informační systém EMS přijímá, eviduje a vyhodnocuje údaje ze všech zařízení umístěných u monitorovaných osob. Pokud jsou získaná data v rozporu s nastavenými podmínkami výkonu trestu domácího vězení nebo v rozporu s povinnostmi uloženými v souvislosti s opatřeními nahrazujícími vazbu, upozorní ihned pracovníky operačního střediska EMS. 


\section{Praktické právní problémy s aplikací omezení podle $\$ 73$ odst. $4 \operatorname{Tr}$ Ř}

Elektronická kontrola prri náhradě vazby se do českého trestního práva dostala novelou trestního rádu provedenou z. č. 150/2016 Sb. s účinností od 1. 7. 2016. Doposud se toto omezení v praxi fakticky nevyužívalo s ohledem na skutečnost, že možnost elektronické kontroly nebyla dotažená do konce po technické stránce. Vše se změnilo v polovině zárí 2018 , kdy byly první náramky nasazovány osobám ve výkonu trestu domácího vězení. Od 23. 9. 2018 byl poté spuštěn ostrý provoz EMS.

V rámci spuštění EMS došlo $\mathrm{v}$ průběhu září a řijna 2018 ke schůzkám mezi soudy, státními zastupitelstvími a PMS jak na okresních, tak krajských úrovních, které měly prípravit hladké fungování systému. Během těchto pracovních schůzek se však objevily i některé právní problémy s možností využití elektronické kontroly podle $\ 73$ odst. 4 TrŘ jako omezení $\mathrm{v}$ prípadě náhrady vazby.

Podle $\int 73$ odst. 4 TrǨ v souvislosti s nabrazenim vazby některým opatrenim uvedeným $v \int 73$ odstavci 1 TrǨ mǔze orgán rozhodujici o vazbè rozhodnout o výkonu elektronické kontroly plnèní povinností uložených v souvislosti s timto opatrenim prostrédnictvím elektronickébo kontrolníbo systému umo žnujicího detekci pobybu obvinènébo, jestliže obvinèný slibí, že prì výkonu elektronické kontroly poskytne veškerou potrebnou součinnost. Préd tím orgán rozhodujici o vaz̧bè obvinènébo pouči o prỉbèbu elektronické kontroly.

Z výše uvedeného ustanovení tedy vyplývá, že samotná elektronická kontrola není dalším opatřením nahrazujícím vazbu (těmi zůstavují opatření uvedená v $\int 73$ odst. 1 Tr ř a $₫ 73 a \operatorname{Tr} \check{R}$ ), ale toliko omezením, které umožňuje výše uvedené opatření učinit efektivnější, obdobně jako zákaz vycestování podle $\int 73$ odst. 5 TrŘ.

S ohledem na míru a rozsah zásahů do osobní a soukromé sféry obviněného, jakož i s ohledem na potřebu jeho aktivní součinnosti prí výkonu elektronické kontroly se však vyžaduje, aby orgán rozhodující o vazbě před rozhodnutím o elektronické kontrole obviněného relativně podrobně poučil o průběhu elektronické kontroly (tj. o povaze a intenzitě zásahu do jeho základních práv a svobod, jejž výkon kontroly představuje), a aby o výkonu elektronické kontroly rozhodl, pouze pokud obviněný slíbí, že prì výkonu elektronické kontroly poskytne veškerou potřebnou součinnost. Důvodem tohoto požadavku je skutečnost, že $\mathrm{v}$ př́padě negativního postoje obviněného $\mathrm{k}$ výkonu elektronické kontroly nelze rozumně předpokládat, že obviněný dostojí všem podmínkám této kontroly. ${ }^{22} \mathrm{~V}$ prrípadech, kdy slib a vyjádření obviněného nebudou dostačovat k posouzení vhodnosti elektronické kontroly, má orgán rozhodující o vazbě možnost si za účelem kvalifikovaného rozhodnutí vyžádat zprávu probačního úředníka obsahující zjiššění o možnostech výkonu elektronické kontroly uložených povinností a k nahrazení vazby přsistoupit až po jejím posouzení.

22 Současně náramek se dá jednoduše pomocí ostrého nástroje odstranit. 
Obdobně možnost uložit elektronický monitoring vedle dalších institutů nahrazujících vazbu pojímá i metodický materiál PMS, označený jako ,informace pro soudce a státní zástupce $\mathrm{k}$ součinnosti s Probační a mediační službou v rámci zajištění elektronického monitoringu“ “23

Právě předchozí šetření a vyžadování zprávy, preferované PMS (možná oprávněně), poněkud komplikuje ukládání omezení podle $\int 73$ odst. 4 TrŘ již v ř́zení o vzetí do vazby ( 68 TrŘ), případně i využití tohoto omezení při žádosti obviněného o propuštění $z$ vazby ( $\left(\int 1 \mathrm{a}\right.$ TrŘ). Důvodem komplikace je skutečnost, že prověření možnosti elektronické kontroly při nahrazení vazby vyžaduje, aby $\boldsymbol{P M S}$ měla jednak možnost prověřit reálnost výkonu elektronické kontroly $\mathrm{v}$ bydlišti obviněného, jednak nelze docillit v současné době instalaci technických koncových zařízení (především náramku) ihned, nejlépe v jednací síni soudu po právní moci rozhodnutí.

\subsection{Nutnost předběžného šetření PMS}

Jak vyplývá z manuálu PMS, je nutné před samotnou instalací náramku provést předběžné šetření, které realizuje PMS. Cílem předběžného šetření je ověřit, zda jsou $\mathrm{v}$ daném př́padě splněny potřebné podmínky a předpoklady pro využití elektronického monitoringu, a to:

- základní technické podmínky nezbytné pro fungování EMS v obydlí (např. pokrytí signálem GPS/GSM, stabilní zdroj elektřiny, charakter obydlí, možnosti jeho bezproblémového zaměření technologií EMS apod.),

- přítomnost rizikových a jiných skutečností v aktuální životní situaci pachatele, které mohou mít podstatný vliv na zajištění elektronického monitoringu (např. zdravotní omezení, druh zaměstnání, stabilita bydlení, rodinná a sociální situace, problémové užívání alkoholu či OPL apod.).

Předběžné šetření zahrnuje především osobní konzultace s obviněným, návštěvu v místě předpokládaného výkonu elektronické kontroly, poučení obviněného o podmínkách výkonu elektronické kontroly a zajištění jeho stanoviska k možnosti využití elektronického monitoringu, ale také konzultace s osobami, kterým př́padné využití EMS zasáhne do běžných zvyklostí (např. rodinní příslušníci, spolubydlícî). Předběžné šetření je z hlediska PMS důležité, aby bylo možné předejít nevhodnému uložení elektronické kontroly v případech, které svou povahou vylučují efektivní a účelné využití EMS, v některých případech předejít následné nemožnosti fakticky zajistit elektronickou kontrolu.

Nelze nic namítat proti předběžnému šetření PMS, je to krok správným směrem především u výkonu trestu domácího vězení ( $\int 60$ TrZ), nebo při přeměně trestu odnětí svobody v trest domácího vězení ( $\int 57 \mathrm{a} T \mathrm{TrZ}$ ), nicméně není přiliš vhodné při rozhodování

23 Jedná se materiál, který není volně šířen a je podkladem pro spolupráci mezi soudy, státním zastupitelstvím a PMS. 
o vazbě. Tím důvodem je doba, kterou PMS potřebuje $\mathrm{k}$ tomu, aby předběžné šetření provedla, a ta je v trvání 3 týdnů. Tato doba nám vylučuje množnost doplnit elektronickou kontrolou opatření nahrazující vazbu jednak při vzetí do vazby ( $\left.\int 68 \mathrm{Tr} \check{R}\right)$, ale i v případě žádosti o propuštění z vazby ( $\int 71 \mathrm{a}$ TrŘ). V př́padě vzetí do vazby má soud na rozhodnutí 24 hodin ( $\$ 77$ odst. 2 TrŘ). V prípadě podané žádosti o propuštění $z$ vazby sice konkrétní lhůty k rozhodnutí stanoveny nejsou, ale $\int 71$ a Tř̌ uvádí, že má být rozhodnuto bez zbytečného odkladu. Novela 459/2011 Sb. s účinností od 1. 1. 2012 sice vypustila pětidenní pořádkovou lhůtu stanovenou pro rozhodnutí soudu o žádosti obviněného o propuštění na svobodu, nadále se však vychází z povinnosti rozhodnout „bez zbytečného odkladu“ ( $\int 71$ a třetí věta $\left.\operatorname{TrR}\right) \cdot{ }^{24}$ Soud je pak povinen o takové žádosti rozhodnout bez zbytečného odkladu, což znamená, že musí rozhodnutí učinit bez průtahů. ${ }^{25}$ Takovou lhůtou pak nejsou tři týdny.

Komplikované bude i využití této možnosti při prodlužování vazby v prrípravném řízení podle $\int 72$ odst. 1 TrŘ a to proto, že státní zástupce, pokud sám dř́ve nedospěje k závěru, že je možné vazbu nahradit některým opatřením s omezením elektronické kontroly, pak je povinen soudu předložit návrh na prodloužení vazby nejpozději 15 dní před uplynutím lhůty tří měsíců ( 72 odst. 2 TrŘ). Z praxe je známo, že státní zástupci nepodávají návrhy na prodloužení vazby až poslední den lhůty, nicméně stává se velmi výjimečně, aby návrh přišel 3 týdny před koncem lhůty podle $\int 72$ odst. $1 \operatorname{Tr}$ Ř.

Pokud bychom přistoupili na výše uvedenou argumentaci PMS, bylo by možné v rámci vazebního řízení nahradit vazbu některým z opatření podle $\int 73$ odst. 1 TrŘ , které zpřísníme elektronickou kontrolou toliko v soudním stadiu řízení, kde má soudce větší časový prostor, pro provedení předběžného šetření ze strany PMS. Bylo by možné využít tohoto omezení při rozhodování podle $\int 72$ odst. 3 TrŘ (po podání obžaloby), kde má soudce na rozhodnutí 30 dní, nebo v případě, pokud v soudním stadiu bude prodlužovat vazbu podle $\int 72$ odst. 1 TrŘ co 3 měsíce. $V$ přípravném řízení přichází v úvahu využité elektronického monitoringu pouze tehdy, pokud rozhodne sám státní zástupce o propuštění z vazby na svobodu.

Komplikací však je, že trestní řád takto využití omezení podle $\int 73$ odst. 4 TrŘ neomezuje, resp. tyto technické záležitosti prŕliš neřeší a tím vzniká řada otázek. Trestní řád nevylučuje elektronický monitoring $\mathrm{v}$ situacích, kdy nejsme technicky připraveni tuto možnost využít. Jaká bude reakce především Ústavního soudu? Můžeme vyloučit z možnosti nahrazení vazby opatřením zpřísněným elektronickou kontrolou výše uvedené osoby, pokud nám zákon dosah tohoto institutu nijak neomezuje?

Jistou roli může hrát to, že elektronická kontrola sama o sobě není opatření, kterým je možné vazbu nahradit, alespoň to tak nevyplývá ze zákonného znění, ale pouze

24 ŠÁMAL, Pavel a kol. Trestní rád. Komentár. 7. vyd. Praha: C. H. Beck, 2013, s. 819.

25 Ibid., s. 822. 
umožňuje opatření nahrazující vazbu zintenzivnit. Nicméně je zřejmé, že bude daleko pravděpodobnější, že soud z vazby pustí nebo do ní nevezme obviněného, který jednak složí písemný slib podle $\int 73$ odst. 1 písm. b) TrŘ a jednak mu bude uložená elektronická kontrola, než obviněnému, který sice složí písemný slib, ale elektronická kontrola mu uložená nebude.

Navíc v ustanovení $\int 73$ odst. 6 TrŘ již trestní řád o elektronickém monitoringu hovoří jako o omezení a současně stanoví pravidla, za jakých okolností může obviněný žádat zrušení takového omezení. Tato pravidla mají velmi blízko k pravidlům, na základě kterých se rozhoduje o propuštění $z$ vazby. ${ }^{26} \mathrm{Je}$ tedy možné uzavřít, že opatření podle $\int 73$ odst. 1 TrŘ doplněné omezením podle $\int 73$ odst. 4 TrŘ dává obviněnému daleko větší možnost na propuštění z vazby (či propuštění se zadržení) než v prrípadě bez tohoto omezení.

Nelze ani neupozornit, že záměr zákonodárce byl jiný. $\mathrm{V}$ důvodové zprávě k z.č. 150/2016 Sb. se lze dočíst, že pưvodně bylo zvažováno více variant jak s omezením podle $\int 73$ odst. 4 TrŘ naložit. Mimo jiné, bylo pracováno také s variantou, že soud bude mít povinnost ve všech případech předtím, než uloží omezení podle $\int 73$ odst. $4 \operatorname{TrR}$, si vyžádat stanovisko PMS. Tato varianta však byla odmítnutá, s poukazem na skutečnost, že stanovení povinnosti soudu vyžádat si ve všech př́padech před rozhodnutím o elektronické kontrole zprávu PMS se nejeví jako vhodné. ${ }^{27}$ Především bylo zdůrazněno, ,... ̌̌e soud rozhoduje o vzetí do vazby v prísných zákonných lhuitách, nebude prïcházet v úvahu, aby mèl zprávu PMS k dispozici jižp pri tomto rozhodováni. Pokud by pricházelo v úvahu stíbáni obvinèného na svobodě pouze za soućasnébo uloženi elektronické kontroly, bez niž by mobl být obrožen účel vazby, byl by soud nucen obvinènébo nejprve vzít do vazby a o př́padném nabrazeni vazby některým alternativním (elektronicky kontrolovaným) opatřenim rozhodnout až dodatečnè, zpravidla prí prezkoumáváni trváni dìvodì vazby, kdy by mél jižz zprávu PMS ke dispozici. Možnost takto omezenébo postupu soudu by v̌̌ak predstavovala pro obvinèné, u nichž by objektivnè byly splnèny podminky pro výkon elektronické kontroly uložených povinností na svobodè, výrazný zásah do jejich ústavně zaručených práv a svobod. "28 Zákonodárce tedy počítá s tím, že nahrazení vazby některým z opatření podle $\int 73$ odst. 1, \73a TrŘ a uložení omezení elektronickou kontrolou bude možné již při vzetí do vazby. Nemůžeme tedy takovou možnost zamítnout jen na základě konstatování, že PMS nebude mít časový prostor k provedení předběžného šetření. Je zjevné, že v krátkých

26 Obviněný má právo kdykoliv žádat o zrušení omezení podle $\int 73$ odst. 4 TrŘ. O takové žádosti musí orgán rozhodující o vazbě rozhodnout bez zbytečného odkladu. Byla-li žádost zamítnuta, mưže ji obviněný, neuvede-li nové důvody, opakovat až po uplynutí tří měsíců ode dne nabytí právní moci rozhodnutí.

27 Důvodová zpráva k zákonu č. 150/2016 ze dne 25. 5. 2015. beck-online [online]. [cit. 10. 11. 2018]. Dostupné z: https://www.beck-online.cz/bo/chapterview-document.seam?documentId= oz5f6mrqge3f6mjvgbpwi6romnqtc\&groupIndex $=0 \&$ rowIndex $=0$

28 Důvodová zpráva k zákonu č. 150/2016 ze dne 25. 5. 2015. beck-online [online]. [cit. 10. 11. 2018]. Dostupné $\quad \mathrm{z}$ : https://www.beck-online.cz/bo/chapterview-document.seam?documentId= oz5f6mrqge3f6mjvgbpwi6romnqtc\&groupIndex $=0 \&$ rowIndex $=0$ 
lhůtách toto předběžné šetření nebude schopen provést nikdo, a tak se dostáváme k otázce, zda tuto možnost vyloučit úplně, a nebo ji provést „,nějak v zákonné lhůtě“. Jedinou možností, jak získat informace zjišt'ované při předběžném šetření v krátké lhůtě podle $\int 77$ odst. 2 TrŘ je, aby tyto informace důležité pro efektivní elektronickou kontrolu zjistil soudce $\mathrm{v}$ rámci vazebního zasedání. Nebude však možné tyto skutečnosti ověřit místním šetřením.

Soudce tedy bude mít dvě možnostmi řešení:

1. Důvěřovat informacím, kterými toho času disponuje (většinou získaných jen z výslechu obviněného, př́padně spisu) a rozhodnout o nahrazení vazby dohledem s využitím elektronické kontroly, nebo rozhodnout o nahrazení vazby jiným opatřením.

2. Rozhodnout o vzetí do vazby a v dalším řízení o nahrazení vazby pověřit PMS zjištěním podmínek pro využití elektronické kontroly.

PMS argumentuje, že je na místě postup podle bodu 2), kdy má za to, že tento postup koresponduje s vyjádřením Oddělení trestněprávní legislativy Ministerstva spravedlnosti, které uvedlo, že „...jsou-li dány vazẹni diovody a soud má pochybnost o vhodnosti uloženi nábradního opatreni za současného uloženi elektronického monitoringu, mữe být prù splnèni zákonných podminek rozhodnuto o vzeti obvinèného do vazby a vyžádána od PMS zpráva k možnosti využiti EMS a na základě predložené zprávy PMS následně mưře být roz̧odnuto o nabrazeni vazby za současnébo vyuriti EMS.“"29

Pokud bychom uvažovali o variantě 1), pak bude muset soud ze spisového materiálu, a především výslechu obviněného u vazebního zasedání důkladně posoudit, zda u obviněného nejsou př́tomny zásadní překážky bránící výkonu elektronické kontroly (aniž by byl soud schopen tyto informace ověrit) a současně bude muset obviněného poučit o podmínkách, povinnostech a omezeních spojených s elektronickou kontrolou a vyžádat slib obviněného, že se bude ve stanoveném čase zdržovat ve svém obydlí a bude při výkonu omezení nahrazení vazby poskytovat veškerou potřebnou součinnost. Zásadními překážkami bránícími výkonu elektronického monitoringu jsou:

- nestabilní bydlení (pachatel často mění místo pobytu, zdržuje se na ubytovnách, je zcela bezprizorní, je ohrožen ztrátou bydliště např. z důvodů neplnění závazků nebo zadluženosti apod.),

- absence stabilního přívodu elektrické energie v obydlí obviněného,

- absence pokrytí signálem GPS/GSM (v současné době službu poskytuje mobilní operátor O2) v oblasti, v níž se obydlí nachází,

- absence vhodného místa v obydlí pro umístění základnové stanice nebo hrozba, že bude stanice v obydlí vystavena neoprávněné manipulaci,

29 PROBAČNÍ A MEDIAČNÍ SLUŽBa. Informace pro soudce a státní zástupce ke součnnosti s probačni a mediační slų̌bou v rámci zajištèni elektronickébo monitoringu. 2018, s. 11. 
- přítomnost prokazatelného zdravotního omezení obviněného, které vylučuje nebo výrazně omezuje možnost nošení elektronického náramku (např. má kardiostimulátor, kožní onemocnění, bércové vředy, často podstupuje vyšetření prostřednictvím CT nebo magnetické rezonance),

- nedostatečná schopnost obviněného obsluhovat monitorovací zařízení a tato zařízení udržovat v chodu pravidelným nabíjením. ${ }^{30}$

PMS oprávněně namítá, že pokud nedojde $\mathrm{k}$ předběžnému šetření, nelze zaručit bezproblémový výkon elektronické kontroly. Mohou nastat i situace, kdy elektronickou formu kontroly nebude možno zajistit vůbec (např́klad ze zdravotních důvodů obviněného, $z$ důvodů technického charakteru apod.) a př́ípad bude vyžadovat další rozhodnutí orgánu činného v trestním řízení.

Je tedy možné uzavřít, že neexistuje dobré řešení, jen dvě nedostatečná. Bud' soudy budou rozhodovat samy o možnostech uložení omezení podle $\int 73$ odst. 4 TrŘ, bez možnosti faktického ověření překážek bránících výkonu elektronické kontroly, nebo tuto možnost nevyužijí, prípadně takový návrh obhajoby budou zamítat s odkazem na nemožnost provést předběžné šetření ze strany PMS (vedoucí k vyloučení překážek bránící elektronickému monitoringu) v prrípadě vzetí do vazby podle $\int 68$ odst. 1 TrŘ $\mathrm{v}$ prrípadě žádostí o propuštění z vazby podle $\int 71 \mathrm{a} T r \mathrm{R}$, případně i v případě prodloužení vazby v př́pravném řízení podle $\int 72$ odst. 1 TrŘ (v návaznosti na $\int 72$ odst. 2 TrŘ). Pro takové zamítnutí však nemají soudy zákonný podklad, jelikož trestní řád uložení omezení podle $\int 73$ odst. 4 TrŘ v těchto př́ipadech nevylučuje. Obávám se, že především Ústavní soud s tímto postupem souhlasit nebude.

\subsection{Nemožnost instalovat náramek v době rozhodnutí}

Ještě bych rád poukázal na jeden problém související s omezením podle $\int 73$ odst. 4 TrŘ ve vztahu k vazbě. PMS neumí zahájit elektronickou kontrolu v době, kdy pachatel bude ze zadržení (nebo z vazby) propuštěn. Představa PMS je taková, že soudy obviněného propustí, uloží mu povinnost dostavit se v konkrétní lhůtě na PMS (2-5 dnî). Propuštěný obviněný si dojde na místně př́íslušné středisko PMS, zde si na něj vezmou telefonický kontakt, vyrozumí specialistu EMS, a ten bude v rámci dní (dle svého pracovního vytíženî) kontaktovat propuštěného obviněného. Domluví si s ním schůzku v jeho bydlišti a teprve poté nainstaluje základovou stanici a propuštěnému obviněnému nasadí náramek, čímž konečně fakticky bude zahájená elektronická kontrola. Specialista EMS totiž za současného stavu věci provádí instalaci a deinstalaci koncových zařízení jen v pracovní dny od 08:00 do 16:30. Po pracovní době nebo o víkendech nezajišt'uje instalaci a aktivaci nových případů. Obávám se, že tento př́stup také nepřispěje k většímu využití tohoto institutu jako náhrady vazby. Myslím si, že pro řadu soudců bude

30 PROBAČNÍ A MEDIAČNÍ SLUŽBA. Informace pro soudce a státní qástupce ke soucinnosti s probačni a mediační službou v rámci zajisténi elektronického monitoringu. 2018, s. 15. 
nepředstavitelné, že obviněný, u něhož shledávají např́klad útěkový důvod vazby, bude nekontrolován v řádu několika dnů od svého propuštění z vazby.

\section{Závěr}

Elektronický monitoring má velký potenciál nejen u trestu domácího vězení či přeměně trestu odnětí svobody na trest domácího vězení, ale i v prrípadě náhrady vazby. Pokud bude zajištěná lokalizace obviněného (bude známo, kde se $\mathrm{v}$ dané chvíli nacházî), pak je zbytečné spoustu obviněných ve vazbě držet nebo do vazby brát. Není př́liš reálné, že se obviněný pokusí skrývat, když má na noze náramek s GPS, stejně tak se nejeví reálné, že by prípadně pokračoval v trestné činnosti, když záznam s lokalizací jeho pohybu je uchováván po dobu 1 roku $^{31}$ a na základě žádosti prrístupný orgánům činným v trestním řízení.

Problém je však v nastavení systému. Má původní představa byla, že poté co mi jako soudci přivedou zadrženou osobu a zjistím, že je u ní dán vazební důvodu, který lze nahradit, tak nahradím vazbu opatřením podle $\int 73$ odst. 1 , př́padně $\int 73 \mathrm{a} \operatorname{TrR}$ a současně uložím omezení podle $\int 73$ odst. 4 TrŘ , které bude realizováno ,ihned“. Ještě než obviněný opustí budovou soudu, bude mít na noze náramek, který bude signalizovat polohu obviněného, a pokud se obviněný pokusí náramek sundat, „ihned“ zakročí PČR. Takový systém by měl smysl, takový systém by řešil otázku přeplněnosti věznic a omezil by množství trestních stíhání, která jsou vedená vazebně.

Systém, tak jak je nastaven nyní, však nepovede k výše uvedenému cíli. Je zřejmé, že snahou ministerstva spravedlnosti je spustit systém, který byl původně plánován pro trest domácího vězení. Možná proto, že se objevila obava, že nebude dostatek osob, kterým by byl trest domácího vězení uložen, došlo k rozšíření využití elektronického monitoringu i na otázku vazby, aniž by proběhla podrobná diskuze. Stejný systém, který může fungovat u trestu domácího vězení, nebude fungovat u vazby.

Vítám možnost elektronického monitoringu obviněných či odsouzených, především u trestu domácího vězení, převodu z nepodmíněného trestu odnětí svobody do domácího vězení a snad časem se prosadí možnost elektronického monitoringu i při podmíněném propuštění (nyní je to možné jen $\mathrm{v}$ případě předčasného podmíněného propuštění podle $\int 88$ odst. 2 TrŘ), ale u vazby tento systém tak jak je nastaven př́liš fungovat nebude. Aby tento systém fungoval lépe, bylo by třeba především, aby specialista EMS byl $\mathrm{k}$ dispozici 24 hodin denně 7 dní v týdnu, aby byl schopen propuštěnému obviněnému náramek nasadit $\mathrm{v}$ krátkém časovém úseku od rozhodnutí soudu. Instalovat základovou stanici je možné i později. Pokud je obviněný propuštěn z vazby, je prioritní, aby byl pod kontrolou, aby ho bylo možné lokalizovat. $\mathrm{K}$ tomu stačí, aby byl obviněnému dán náramek, už ten sám o sobě dokáže osobu lokalizovat. Navíc oproti trestu

31 Záznam s pohybem obviněného je uchováván po dobu 1 roku operačním střediskem. 
domácího vězení nemusí být ani nutností, aby obviněný měl stálé bydliště. Musí mít jen přístup k elektrické energii, aby mohl náramek dobíjet, což by bylo možné vyřrešit v rámci dohledu v budovách PMS. Pokud budeme vyžadovat předběžné šetření, mohla by PČR již v rámci zadržení prověřit překážky bránící elektronickému monitoringu (jde především o ověření místa výkonu omezení, přítomnost signálu GPS a prrívod elektrické energie). Pokud opravdu chceme elektronickou kontrolou vazbu nahrazovat, nevyhneme se do budoucna konkrétně zaměřené diskuzi, která umožní elektronickou kontrolu využívat častěji, aniž by došlo k ohrožení účelu vazby. 